\title{
ANALISIS DAMPAK ANGGARAN PENDAPATAN DAN BELANJA DERAH TERHADAP PERTUMBUHAN EKONOMI, KEMISKINAN DAN PENGAGGURAN DI SULAWESI UTARA
}

\author{
Debby Ch. Rotinsulu, Avriano R. Tenda, Luciana M. Leonufina \\ Fakultas Ekonomi dan Bisnis, Ilmu Ekonomi Pembangunan \\ Universitas Sam Ratulangi, Manado
}

\begin{abstract}
ABSTRAK
Pertumbuhan ekonomi, angka kemiskinan serta pengangguran tentunya tidak lepas dari peran serta pemerintah sebagai pengambil kebijakan serta kuasa penggunaan anggaran untuk dapat merangsang perekonomian menuju ke arah yang lebih baik melalui Anggaran Pendapatan dan Belanja Daerah yang tentunya diharapkan akan mempercepat roda perekonomian. Dengan adanya perputaran cepat roda perekonomian diharapkan akan membuka peluang ekonomi baru yang tentunya akan menarik tenaga kerja yang berdampak pada penurunan angka pengangguran dan meningkatkan taraf hidup masyarakat dan tidak lagi terpuruk pada jurang kemiskinan. Untuk itu dalam penelitian ini bertujuan untuk melihat seberapa pengaruh pemerintah melalui APBD nya dalam meningkatkan pertumbuhan, menekan angka pengangguran dan mengurangi kemiskinan di Kabupaten, Kota di wilayah Sulawesi Utara.
\end{abstract}

\section{Kata Kunci: APBD, Belanja Modal, Pertumbuhan Ekonomi, Kemiskinan, pengangguran}

\begin{abstract}
Economic growth, poverty and unemployment must not be separated from the role of government as policy makers and power use of the budget to stimulate the economy towards better through the Regional Budget which is certainly expected to accelerate the economy. With the quick turnaround of the economy is expected to open up new economic opportunities that will attract workers who have an impact on the growth of unemployment and improve people's lives and can no longer hit in poverty. Therefore in this study aims to see how the government's influence over its budget to boost growth, reduce unemployment and reduce poverty in the District, City in the North Sulawesi.
\end{abstract}

Keywords: Regional Government Budget, Capital Expenditures, Economic Growth, Poverty, Unemployment 


\section{PENDAHULUAN}

\section{Latar Belakang Permasalahan}

Pembangunan merupakan suatu proses perubahan secara multidimensional yang menurut Todaro (2006) mencakupberbagaiperubahan mendasar atas struktur sosial, sikap-sikapmasyarakat dan institusi-institusi nasional, disamping tetap mengejar akselerasi pertumbuhan ekonomi, penanganan ketimpangan pendapatan, serta pengentasan kemiskinan. Demikian juga proses pembangunan yang dilakukan di Negara Indonesia bertujuan untuk mencapai masyarakat yang adil dan makmur. Hal ini berarti bahwa kesejahteraan masyarakat adalah tujuan penting dari penyelengaraan pembangunan.

Hasil penelitian tim peneliti BAPPENAS mengatakan bahwa pola pembangunan di Indonesia bukanlah merupakan Auto pilot Pembangunan nasional Indonesia secara keseluruhan tidak lepas dari pembangunan daerah-daerah di seluruhProvinsi. Keberhasilan pembangunan di setiap daerah akan menentukan keberhasilan pembangunan nasional. Oleh karena itu proses pembangunan daerah perlu di dorong kearah peningkatan yang lebih baik dengan cara memberikan kewenangan bagi masing-masing daerah untuk melaksanakan pembangunan. Pemberian kewenangan ini di lakukan melalui semangat otonomi daerah. Pembangunan daerah mencakup semua kegiatan pembangunan daerah dan sektoral yang berlangsung di daerah yang dilakukan oleh pemerintah dan masyarakat (Nugroho dan Rochim Danuri, 2004).

Otonomi daerah telah menyebabkan pergeseran dalam paradigma pembangunan di Indonesia. Semula penyelenggaraan pembangunan didasarkan pada asas sentralisasi, kemudian berubah ke asas desentralisasi. Ini menandakan bahwa pemerintah daerah mempunyai kewenagan untuk mengelola daerahnya termasuk mengelola keuangan daerahnya. Namun perlu dipahami walaupun daerah punya kewenangan untuk mengatur sendiri, tapi pengelolaan keuangan haruslah berdasarkan Undang-Undang nomor 17 tahun 2003 tentang Pengelolaan keuangan Negara.

Suatu daerah untuk dapat melaksanakan suatu pembangunan dan mengurus rumah tangganya sendiri harus mempunyai sumber-sumber keuangan sendiri yang cukup. Hal ini untuk menghindari ketergantungan yang semakin besar bagi daerah pada pemerintah pusat atau daerah tingkat atas nya. Hal ini tentu tak bisa terjadi apabila proses pengelolaan sumber-sumber pendapatan dari sector ekonomi potensial tidak dikelola dengan baik. Untuk itu pemerintah daerah dituntut bukan hanya bisa menjalankan kewenangan yang diberikan namun juga harus bisa menjalankan tanggung jawab sebagai sebuah daerah otonomi yakni meningkatkan kemandiriannya dalam bentuk penerimaan Pendapatan Asli Daerah (PAD) dan sedikit demi sedikit 
mengurangi prosentase pendapatan yang berasal dari dana perimbangan pemerintah pusat. Masih kurangnya tingkat kemandirian pemerintah daerah dan masih besarnya factor ketergantungan kepada pemerintah pusat yang masih amat besar, sehingga banyak kebijakan pemerintah pusat dan pengelolaan potensi sumber keuangan harus diikuti oleh pemerintah daerah, serta sumber-sumber keuangan potensial yang masih dikuasai oleh pemerintah pusat (Yani, 2002). Dalam hubungannya sendiri, dana perimbangan merupakan salah satu komponen utama yang mempengaruhi tingkat kemampuan daerah dalam mencukupi anggaran belanjanya untuk setiap periode yang berjalan, hubungan ini sendiri bersifat (Intergovermental fiscal relation system).

Sulawesi Utara merupakan sebuah wilayah di bagian Indonesia Timur dan berada di ujung Utara pulau Sulawesi. Merupakan sebuah daerah dengan berbagai potensi, mulai dari posisinya sebagai daerah yang bisa menjadi pintu perdagangan dunia karena letaknnya yang berada di bibir pasifik dan pelabuhan internasional yang dimiliki. Selain itu pembangunan juga tengah gencar di bangun di daerah ini, mulai dari pembangunan Tol Manado-Bitung sepanjang 39,9 Kilometer yang akan menjadi penghubung dan mempercepat perputaran ekonomi yang terjadi di daerah yang juga akan meningkatkan potensi kota Bitung yang sudah memiliki Pelabuhan Bitung yang menjadi International Hub Port (IHP), serta mempercepat pembangunan Kawasan Ekonomi Khusus (KEK) yang akan dibangun di Minahasa Utara dan Bitung.

\section{Perumusan Masalah}

Berdasarkan latar belakang di atas maka peneliti tertarik untuk mengatahui bagaimana pengaruh pendapatan asli daerah dan pendapatan dana alokasi khusus terhadap belanja modal

\section{Tujuan Penelitian}

Berdasarkan identifikasi masalah yang telah terurai maka yang menjadi tujuan dari penelitian ini adalh untuk mengetahui berapa besaran pengaruh Pendapatan Asli Daerah (PAD) dan Dana Alokasi Khusus (DAK) terhadap Belanja Modal.

\section{Manfaat Penelitian}

1. Bagi pemerintah daerah penelitian ini diharapkan dapat memberikan informasi pentingnya mengoptimalkan potensi local yang dimiliki daerah untuk peningkatan kualitas pengelolaan keuangan yang nantinya akan berdampak pada kesejahteraan masyarakat.

2. Sebagai bahan referensi dan informasi bagi masyarakat dan mahasiswa/I yang ingin melakukan penelitian selanjutnya. 
3. Untuk menambah dan memperkaya wawasan ilmiah penulis dalam disiplin ilmu yang penulis tekuni.

\section{LANDASAN TEORI}

\section{Anggaran Pendapatan dan Belanja Daerah (APBD)}

Anggaran Pendapatan dan Belanja Daerah (APBD) adalah suatu rencana kerja pemerintah yang dinyatakan secara kuantitatif, biasanya dalam satuan moneter yang mencerminkan sumber-sumber penerimaan daerah dan pengeluaran untuk membiayai kegiatan dan proyek daerah dalam kurun waktu satu tahun anggaran. Pada hakekatnya anggaran daerah (APBD) merupakan salah satu alat untuk meningkatkan pelayanan publik dan kesejahteraan masyarakat sesuai dengan tujuan otonomi daerah yang luas, nyata dan bertanggungjawab. Dengan demikian APBD harus benar-benar dapat mencerminkan kebutuhan masyarakat dengan memperhatikan potensi-potensi keanekaragaman daerah (Lasminingsih, 2004 : 223).

Dalam APBD pendapatan dibagi menjadi 3 kategori yaitu Pendapatan Asli Daerah (PAD), Dana Perimbangan, dan Lain-lain Pendapatan Daerah yang Sah. Selanjutnya Belanja digolongkan menjadi 4 yakni Belanja Aparatur Daerah, Belanja Pelayanan Publik, Belanja Bagi Hasil dan Bantuan Keuangan, dan Belanja Tak Tersangaka. Belanja Aparatur Daerah diklasifikasikan menjadi 3 kategori yaitu Belanja Administrasi Umum, Belanja Operasi dan Pemeliharaan, dan Belanja Modal / Pembangunan. Belanja Pelayanan Publik dikelompokkan menjadi 3 yakni Belanja Administrasi Umum, Belanja Operasi dan Pemeliharaan, dan Belanja Modal. Pembiayaan seperti sudah dikatakan di atas, adalah sumber - sumber penerimaan dan pengeluaran daerah yang dimaksudkan untuk menutup defisit anggaran atau sebagai alokasi surplus anggaran. Pembiayaan dikelompokkan menurut sumber-sumber pembiayaan, yaitu : sumber penerimaan daerah dan sumber pengeluaran daerah. Sumber pembiayaan berupa penerimaan daerah adalah: sisa lebih anggaran tahun lalu, penerimaan pinjaman dan obligasi, hasil penjualan aset daerah yang dipisahkan, dan transfer dari dana cadangan. Sedang sumber pembiayaan berupa pengeluaran daerah terdiri atas: pembayaran utang pokok yang telah jatuh tempo, penyertaan modal, transfer ke dana cadangan, dan sisa lebih anggaran tahun sekarang.

\section{Pertumbuhan Ekonomi}

Secara umum, pertumbuhan ekonomi didefenisikan sebagai peningkatan kemampuan dari suatu perekonomian dalam memproduksi barang-barang dan jasajasa. Pertumbuhan ekonomi adalah salah satu indikator yang amat penting dalam melakukan analisis tentang pembangunan ekonomi yang terjadi pada suatu negara. Pertumbuhan ekonomi menunjukkan sejauh mana aktivitas perekomian akan menghasilkan tambahan pendapatan masyarakat pada suatu periode tertentu. Karena pada dasarnya aktivitas perekonomian adalah suatu proses penggunaan faktor-faktor produksi untuk menghasilkan output, maka proses ini pada gilirannya akan menghasilkan suatu aliran balas jasa terhadap faktor produksi yang dimiliki oleh masyarakat. Dengan adanya pertumbuhan ekonomi maka diharapkan pendapatan masyarakat sebagai pemilik faktor produksi juga akan meningkat. Dengan perkataan 
lain bahwa pertumbuhan ekonomi lebih menunjuk kepada perubahan yang bersifat kuantitatif (quantitative change) dan biasanya diukur dengan menggunakan data Produk Domestik Bruto (PDB) atau pendapatan atau nilai akhir pasar (total market value) dari barang-barang akhir dan jasa-jasa (final goods and services) yang dihasilkan dari suatu perekonomian selama kurun waktu tertentu (biasanya satu tahun). Perlu diketahui bahwa pertumbuhan ekonomi berbeda dengan pembangunan ekonomi, kedua istilah ini mempunyai arti yang sedikit berbeda. Kedua-duanya memang menerangkan mengenai perkembangan ekonomi yang berlaku. Tetapi biasanya, istilah ini digunakan dalam konteks yang berbeda. Pertumbuhan selalu digunakan sebagai suatu ungkapan umum yang menggambarkan tingkat perkembangan sesuatu negara, yang diukur melalui persentasi pertambahan pendapatan nasional riil. Istilah pembangunan ekonomi biasanya dikaitkan dengan perkembangan ekonomi di negara-negara berkembang. Dengan perkataan lain, dalam mengartikan istilah pembangunan ekonomi, ahli ekonomi bukan saja tertarik kepada masalah perkembangan pendapatan nasional riil, tetapi juga kepada modernisasi kegiatan ekonomi, misalnya kepada usaha merombak sektor pertanian yang tradisional, masalah mempercepat pertumbuhan ekonomi dan masalah perataan pembagian pendapatan (Sukirno, 2006:423).

\section{Kemiskinan.}

Kemiskinan merupakan masalah kemanusiaan yang telah lama diperbincangkan karena berkaitan dengan tingkat kesejahteraan masyarakat dan upaya penanganannya. Dalam Panduan Keluarga Sejahtera (1996: 10) kemiskinan adalah suatu keadaan dimana seorang tidak sanggup memelihara dirinya sendiri dengan taraf kehidupan yang dimiliki dan juga tidak mampu memanfaatkan tenaga, mental maupun fisiknya dalam memenuhi kebutuhannya. Dalam Panduan IDT (1993: 26) bahwa kemiskinan adalah situasi serba kekurangan yang terjadi bukan karena dikehendaki oleh si miskin, melainkan karena tidak dapat dihindari dengan kekuatan yang ada padanya.

Kemiskinan ini ditandai oleh sikap dan tingkah laku yang menerima keadaan yang seakan-akan tidak dapat diubah yang tercermin di dalam lemahnya kemauan untuk maju, rendahnya kualitas sumber daya manusia, lemahnya nilai tukar hasil produksi, rendahnya produktivitas, terbatasnya modal yang dimiliki berpartisipasi dalam pembangunan.

Mengamati secara mendalam tentang kemiskinan dan penyebabnya akan muncul berbagai tipologi dan dimensi kemiskinan karena kemiskinan itu sendiri multikompleks, dinamis, dan berkaitan dengan ruang, waktu serta tempat dimana kemiskinan dilihat dari berbagai sudut pandang. Kemiskinan dibagi dalam dua kriteria yaitu kemiskinan absolut dan kemiskinan relatif. Kemiskinan absolut adalah kemiskinan yang diukur dengan tingkat pendapatan yang dibutuhkan untuk memenuhi kebutuhan dasarnya sedangkan kemiskinan relatif adalah penduduk yang telah memiliki pendapatan sudah mencapai kebutuhan dasar namun jauh lebih rendah dibanding keadaan masyarakat sekitarnya. Kemiskinan menurut tingkatan kemiskinan adalah kemiskinan sementara dan kemiskinan kronis. Kemiskinan sementara yaitu kemiskinan yang terjadi sebab adanya bencana alam dan kemiskinan kronis yaitu 
kemiskinan yang terjadi pada mereka yang kekurangan ketrampilan, aset, dan stamina (Aisyah, 2001: 151).

\section{Jenis Data dan Sumber Data}

\section{METODE PENELITIAN}

Data yang digunakan didalam penelitian ini adalah data sekunder, data yang telah ada dan tersedia baik di buku-buku literatur dan dari hasil materi perkuliahan ataupun sumber-sumber lain yang di peroleh dari Badan Pusat Statistik dan Laporan Realisasi Anggaran 15 Kabupaten/kota di Sulawesi Utara serta data pendukung lainnya yang di butuhkan.

\section{Teknik Pengumpulan Data}

Untuk memperoleh data dan informasi yang diperlukan, maka pengumpulan data dan informasi tersebut dilakukan dengan cara sebagai berikut :

1. Data diperoleh dari Badan Pusat Statistik (BPS).

2. Data atau infomasi yang diperoleh dari buku refrensi, jurnal, majalah, suratkabar yang berkaitan dengan penelitian ini.

3. Pengambilan data langsung di 15 kabupaten/kota Se-Sulawesi Utara

\section{Definisi Operasional dan Pengukuran Variabel}

1. APBD adalah Perkiraan Penerimaan Daerah 15 kabupaten Kota Se Sulawesi Utara yang terdiri atas PAD, Dana Perimbangan,Pinjaman daerah dan,lain lain PAD yang sah, yang di ukur dalam satuan Rupiah.

2. Belanja daerah adalah Pembelanjaan yang dilakukan oleh 15 kabupaten Kota Se Sulawesi Utara yang terdiri atas Belanja langsung dan tidak langsung yang di ukur dalam Satuan Rupiah/Tahun.

3. Kemiskinan adalah kemampuan masyarakat dalam memenuhi kebutuhannya

4. Pertumbuhan Ekonomi adalah perhitungan yang dilakukan berdasarkan total pendapatan nasional/daerah dari tahun ke tahun.

5. Pengangguran adalah jumlah orang yang sudah berada di usia produktif namun tidak bekerja.

\section{Rasio Indeks Kemampuan Rutin}

\section{Metode Analisis Data}

Indeks Kemampuan Rutin dapat dilihat melalui proporsi antara PAD dengan pengeluaran rutin tanpa transfer dari pemerintah pusat. Besarnya kemampuan PAD dalam membiayai pengeluaran rutinnya mempunyai beberapa tahapan kategori yang dapat dilihat dalam tabel 1 . 
Tabel 1 Skala Interval Indeks Kemampuan Rutin.

\begin{tabular}{|c|c|}
\hline \% & Kemampuan Keuangan Daerah \\
\hline $00,00-20,00$ & Sangat kurang \\
\hline $20,01-40,00$ & Kurang \\
\hline $40,10-60,00$ & Cukup \\
\hline $60,10-80,00$ & Baik \\
\hline $80,10-100$ & sangat baik \\
\hline
\end{tabular}

Sumber: Tim Fisipol UGM

Dapat dilihat dalam Tabel diatas bahwa, kemampuan PAD daerah dalam membiayai pengeluaran rutinnya terbagi dalam 5 kategori dengan jarak interval $20 \%$ per kategorinya, yakni indeks kemampuan rutin dibawah $20 \%$ digolongkan sangat kurang, sedangkan 20,1-40\% masih masuk dalam kategori kurang, dan 40,1-60\% sudah berada dalam kategori cukup untuk membiayai pengeluaran rutinnya meskipun masih tetap bergantung setengah pembiayaan pengeluaran rutinnya kepada pemerintah pusat, sedangkan 60,1-80\% masuk kategori baik, dan 80,1-100\% masuk kategoti sangat baik, Indek Kemampuan Rutin dapat dihitung dengan menggunakan rumus sebagai berikut:

$$
\text { Index Kemampuan Rutin }=\frac{\text { Pendapatan Asli Daerah }}{\text { Total Pengeluaran Rutin }} \times 100
$$

Sumber :(Depdagri, 1991)

\section{Rasio Pertumbuhan}

$$
r=\frac{P n-P o}{P_{o}}
$$

$\mathrm{r}=$ Pertumbuhan

$\mathrm{Pn}=$ data yang di hitung pada tahun ke $-\mathrm{n}$ (PAD tahun berjalan di 15 Kabupaten/Kota Se-Sulut)

Po = Data yang di hitung pada tahun ke $-\mathrm{n}$ (PAD tahun Sebelumnya di 15 kabupaten/kota Se-Sulut)

Apabila semakin tinggi nilai PAD, TPD dan belanja pembangunan yang di ikuti oleh semakin rendahnya belanja rutin, maka pertumbuhanya adalah positif. Artinya bahwa daerah yang bersangkutan telah mampu mempertahankan dan meningkatkan pertumbuhanya dari periode yang satu ke periode berikutnya. Jika semakin tinggi nilai PAD, TPD, dan belanja rutin yang diikuti oleh semakin rendahnya belanja pembangunan, maka pertumbuhannya adalah negatif. Artinya bahwa daerah yang bersangkutan belum mampu mempertahankan dan meningkatkan pertumbuhanya dengan dari periode yang satu ke periode yang berikutnya. 


\section{Model Regresi}

Alat analisis yang digunakan adalah analisis regresi linier yang digunakan untuk melihat pengaruh APBD terhadap pengeluaran Pertumbuhan ekonomi, kemiskinan dan Pengangguran. Data diolah dengan bantuan software SPSS seri 21.00. Pengujian hipotesis dilakukan dengan menggunakan model analisis regresi variabel independen terhadap variabel dependen (sekaran, 1992). Ada dua persamaan regresi, persamaan regresi adalah:

\section{Uji Hipotesis}

Ketepatan fungsi regresi sampel dalam menaksir nilai aktual dapat diukur dari Goodness of Fitnya. Secara statistik, setidaknya ini dapat diukur dari nilai koefisien determinasi, nilai statistik $\mathrm{F}$ dan nilai statistik $\mathrm{t}$. Perhitungan statistik disebut signifikan secara statistik apabila nilai uji statistiknya berada dalam daerah kritis (daerah dimana Ho ditolak). Sebaliknya disebut tidak signifikan bila nilai uji statistiknya berada dalam daerah dimana Ho diterima (Ghozali, 2006).

\section{Koefisien Determinasi}

Koefisien determinasi $\left(\mathrm{R}^{2}\right)$ pada intinya mengukur seberapa jauh kemampuan model dalam menerangkan variasi variabel independen. Koefisien determinasi ini digunakan karena dapat menjelaskan kebaikan dari model regresi dalam memprediksi variabel dependen. Semakin tinggi nilai koefisien determinasi maka akan semakin baik pula kemampuan variabel independen dalam menjelaskan variabel dependen (Ghozali, 2006). Nilai koefisien determinasi adalah antara nol dan satu. Nilai $\mathrm{R}^{2}$ yang kecil berarti kemampuan variabel-variabel independen dalam menjelaskan variasi variabel dependen amat terbatas. Nilai yang mendekati satu berarti variabelvariabel independen memberikan hampir semua informasi yang dibutuhkan untuk memprediksi variasi variabel dependen. Dimana :

$\mathrm{Y} 1=\alpha 1+\mathrm{X} 1+\mathrm{e} \quad$. $\quad . \quad \ldots$

Keterangan :

Y1 = kemiskinan

$\alpha=$ konstanta

$\mathrm{X} 1=\mathrm{APBD}$

$\mathrm{e}=$ error term

$\mathrm{Y} 1=\alpha 1+\mathrm{X} 1+\mathrm{e}$

Keterangan :

$\mathrm{Y} 1$ = Pertumbuhan Ekonomi

$\alpha=$ konstanta

$\mathrm{X} 1=\mathrm{APBD}$

$\mathrm{e}=$ error term

$\mathrm{Y} 1=\alpha 1+\mathrm{X} 1+\mathrm{e}$ 
Keterangan :

$\mathrm{Y} 1$ = Pengangguran

$\alpha \quad=$ konstanta

$\mathrm{X} 1=\mathrm{APBD}$

$\mathrm{e}=$ error term

\section{Uji Signifikansi Simultan (Uji Statistik F)}

Uji Statistik F pada dasarnya menunjukkan apakah semua variabel independen atau bebas yang dimasukkan dalam model mempunyai pengaruh secara bersama-sama terhadap variabel dependen (Ghozali, 2006). Cara untuk mengetahuinya yaitu dengan membandingkan nilai $\mathrm{F}$ hitung dengan nilai $\mathrm{F}$ tabel. Apabila nilai $\mathrm{F}$ hitung lebih besar daripada nilai $\mathrm{F}$ tabel, maka hipotesis alternatif diterima artinya semua variabel independen secara bersama-sama dan signifikan mempengaruhi variabel dependen.

\section{Uji Signifikansi Parameter Individual (Uji Statistik t)}

Uji statistik t pada dasarnya menunjukkan seberapa jauh pengaruh satu variabel independen secara individual dalam menerangkan variasi variabel dependen (Ghozali, 2006). Uji statistik t ini digunakan karena untuk memperoleh keyakinan tentang kebaikan dari model regresi dalam memprediksi. Cara untuk mengetahuinya yaitu dengan membandingkan nilai t hitung dengan nilai t tabel. Apabila nilai t hitung lebih besar dibandingkan dengan nilai t tabel maka berarti t hitung tersebut signifikan artinya hipotesis alternatif diterima yaitu variabel independen secara individual mempengaruhi variabel dependen. Selain itu, bisa juga dilakukan dengan melihat $p$ value dari masing-masing variabel. Hipotesis diterima apabila $p$-value $<5 \%$ (Ghozali, 2006).

\section{Hasil Dan Pembahasan}

\section{PDRB menurut Penggunaan}

Pada tahun 2014, PDRB yang digunakan untuk aktivitas konsumsi rumah tangga sebesar 46,62 persen, dimana pengeluaran yang digunakan untuk makanan sebesar 19,31 persen dan sisanya pengeluaran bukan makanan 27,31 persen. Sekitar 34,15 persen dari total PDRB tercatat sebagai Pembentukan Modal Tetap Bruto. Sementara itu aktivitas ekspor luar negeri memberikan andil sebesar 19,33 persen. Komponen pengeluaran konsumsi pemerintah masih merupakan komponen penting bagi perekonomian Sulawesi Utara yang memberikan kontribusi yang tidak sedikit yakni 17,36 persen. 


\section{Rupiah) \\ Grafik 1 Perkembangan PDRB Sulawesi Utara 2010-2014 (Jutaan}

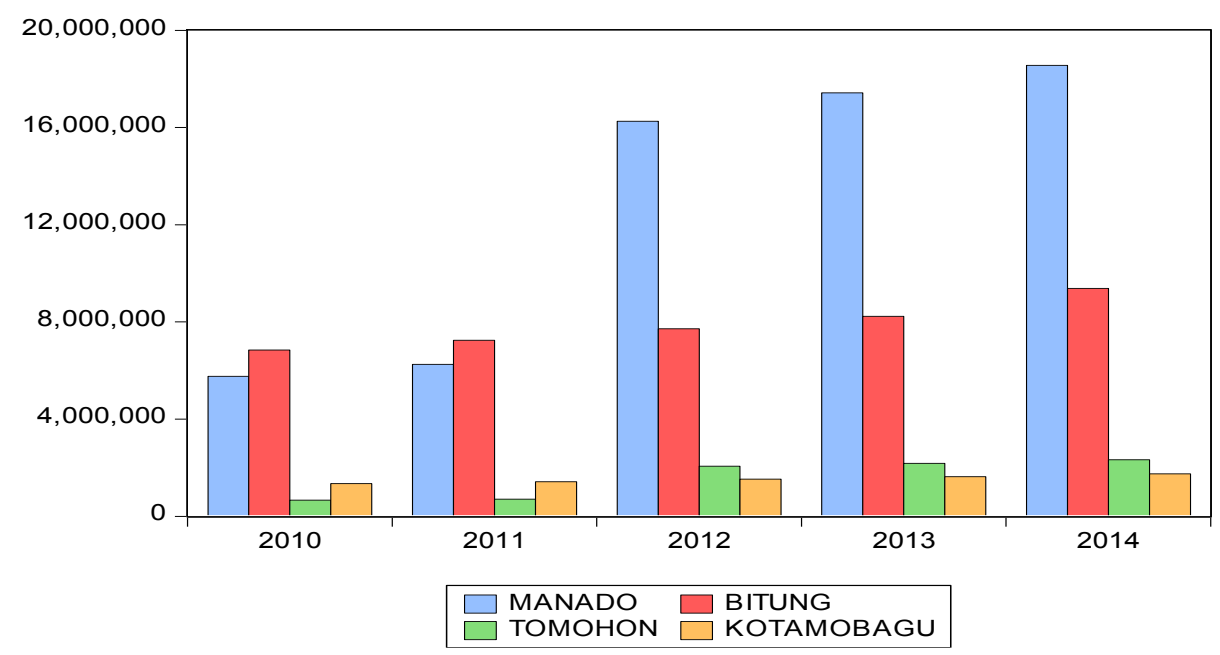

Sumber : BPS Kota Manado (Data diolah)

\section{Rasio Derajat Desentralisasi Fiskal}

Rasio ini menunjukkan derajat kontribusi PAD terhadap total penerimaan daerah. Semakin tinggi kontribusi PAD maka semakin tinggi kemampuan pemerintah daerah dalam penyelenggaraan desentralisasi. Berikut adalah formula perhitungan rasio derajat desentralisasi:

$$
\text { Derajat Desentralisasi }=\frac{P A D}{\text { Total Pendapatan daerah }} X 100 \%
$$

\section{Tabel 2 Kriteria Penilaian Desentralisasi Fiskal}

\begin{tabular}{|c|c|}
\hline Presentase PAD Terhadap TPD & Tingkat Desentralisasi Fiskal \\
\hline $0,00-10.00$ & Sangat Kurang \\
\hline $10,01-20,00$ & Kurang \\
\hline $20,01-30.00$ & Sedang \\
\hline $30,01-40,00$ & Cukup \\
\hline $40,01-50,00$ & Baik \\
\hline$>50,00$ & Sangat Baik \\
\hline
\end{tabular}

Sumber : Tim Litbang Depdagri - Fisipol UGM, 1991

Derajat desentralisasi perkotaan di Sulawesi Utara pada periode 2010-2014 menunjukkan trend positif, namun belum berperan dengan baik sebagai derajat desentralisasi fiskal dimana dari rata-rata perkotaan di Sulawesi Utara memiliki 
tingkat desentralisasi fiskal (DF) yang masih kurang apabila dibandingkan dengan kriteria penilaian desentralisasi fiskal pada tabel 4.1, dimana untuk mempunyai tingkat desentralisasi yang sedang harus mencapai 20,01\% PAD terhadap Total pendapatan daerah (TPD). Hal ini menunjukkan bahwa performa dari kota-kota yang ada disulawesi utara belum mampu untuk mengolah keuangan daerahnya sendiri dan masih sepenuhnya bergantung ke pusat. Hal ini dapat dilihat pada tabel penunjang dibawah ini 4.2 dibawah ini:

Tabel 3 Tingkat Derajat Desentralisasi Fiscal Perkotaan

Di Sulawesi Utara tahun 2010-2015

\begin{tabular}{|c|c|c|c|c|c|c|c|}
\hline \multirow{2}{*}{ Kota } & \multicolumn{5}{|c|}{ Derajat Desentralisasi (\%) } & \multirow{2}{*}{ Rata-rata } & \multirow{2}{*}{ Tingkat DF } \\
\hline & 2010 & 2011 & 2012 & 2013 & 2014 & & \\
\hline Manado & 15.11 & 17.89 & 17.42 & 16.83 & 17.92 & 17.03351189 & Kurang \\
\hline Bitung & 4.23 & 5.18 & 6.92 & 8.47 & 11.21 & 7.19998118 & Sangat Kurang \\
\hline Tomohon & 1.65 & 2.11 & 2.89 & 2.99 & 3.83 & 2.695407969 & Sangat Kurang \\
\hline Kotamobagu & 1.07 & 2.35 & 3.03 & 3.35 & 5.14 & 2.986859711 & Sangat Kurang \\
\hline
\end{tabular}

Data diolah, Excel (2016)

\section{Hasil Regresi Model 1-12}

Model yang digunakan dalam penelitian ini menjadikan variabel Kemiskinan, Pertumbuhan Ekonomi dan pengangguran sebagai variabel tidak bebas, dan yang menjadi variabel bebas yaitu Anggaran Pendapatan dan Belanja Daerah (APBD). Estimasi dilakukan dengan metode Ordinary Least Square.

Pengujian Asumsi klasik

Diagram Uji Heterokoledasitas

Berdasarkan pengukian heterokedastisitas yang dilakukan terhadap model 1-12 dapat dilihat bahwa penyebaran dot pada diagram terpencar dengan tidak membentuk pola tertentu sehingga bias diambil kesimpulan bahwa model 1 sampai 12 tidak terjadi gejala heterokedastisitas. (lihat lampiran)

\section{Uji Autokorelasi}

Tabel 4 Uji Aotukorelasi

\begin{tabular}{|c|c|c|c|c|c|}
\hline \multirow[b]{2}{*}{ Model } & \multicolumn{3}{|c|}{ Change Statistics } & \multirow[b]{2}{*}{$\begin{array}{l}\text { Durbin- } \\
\text { Watson } \\
\end{array}$} & \multirow[t]{2}{*}{ Ket } \\
\hline & $\begin{array}{l}\text { R Square } \\
\text { Change }\end{array}$ & F Change & Sig. F Change & & \\
\hline 1 & .401 & 5.362 & 049 & 1.506 & Kem (mdo) \\
\hline 2 & .144 & .275 & 0279 & 1.180 & PE(mdo) \\
\hline
\end{tabular}


Tabel 4 Uji Aotukorelasi

\begin{tabular}{|c|c|c|c|c|c|}
\hline \multirow[b]{2}{*}{ Model } & \multicolumn{3}{|c|}{ Change Statistics } & \multirow[b]{2}{*}{$\begin{array}{l}\text { Durbin- } \\
\text { Watson }\end{array}$} & \multirow[t]{2}{*}{ Ket } \\
\hline & \begin{tabular}{|l} 
R Square \\
Change \\
\end{tabular} & F Change & Sig. F Change & & \\
\hline 3 & .014 & .116 & .742 & 2336 & Peng (mdo) \\
\hline 4 & .841 & 42.197 & 000 & 2.035 & Kem (btg) \\
\hline 5 & .562 & 10.268 & .013 & 1.08 & Peng(btng) \\
\hline 6 & .554 & 9.953 & .013 & .939 & Pe (btg) \\
\hline 7 & .242 & 2.554 & 1.49 & .908 & Kem (BM) \\
\hline 8 & .409 & 5.530 & 047 & 1.748 & Peng (BM) \\
\hline 9 & .885 & 61.729 & 0.000 & 1.573 & PE (BM) \\
\hline 10 & .111 & .994 & 345 & 1.560 & $\operatorname{Kem}(\mathrm{Mn})$ \\
\hline 11 & .361 & 4.513 & .066 & 1.158 & Peng (Mn) \\
\hline 12 & .417 & 7.431 & 0.26 & 2.083 & $\mathrm{Pe}(\mathrm{Mn})$ \\
\hline
\end{tabular}

a. Dependent Variable: Pertumbuhan Ekonomi, Kemiskinan, Pengangguran

b. Predictors: (Constant), APBD

Sumber data : Pengolahan Data 2016

Berdasarkan hail regresi uji durbin Watson diatas dapat dilihat bahwa pada DW, $\alpha=5 \%$ dengan banyaknya observasi sebanyak 10 pada masing-masing model dengan $\mathrm{K}$ sebanyak satu didapatkan hasil $\mathrm{dL}=0,879$ dan $\mathrm{dU}$ sebesar 1.3197 dengan demikian apabila mengambil perbandingan pada table durbin Watson diatas dapat dilihat bahwa semua model berada pada titik lebih besar dari dL dan lebih kecil dai dU sehingga dapat diambil kesimpulan bahwa semua model lolos uji autokorelasi

\section{Multikorelasi}

Untuk melihat gejala Multiokrelasi dapat dilihat dengan cara sebagai berikut Bila VIF $<10,00$ maka tidak terjadi gejala Multikolerasi

Bila VIF $>10,00$ maka terjadi gejala Multikolerasi 
Tabel 5 uji multikorelasi

\begin{tabular}{|c|l|l|}
\hline Model & VIF & Keterangan \\
\hline 1 & 1.000 & Manado (kemiskinan) \\
\hline 2 & 1.000 & Manado (Pengangguran) \\
\hline 3 & 1.000 & Manado (pertumbuhan Ekonomi) \\
\hline 4 & 1.000 & Bitung (kemiskinan) \\
\hline 5 & 1.000 & Bitung (Pengangguran) \\
\hline 6 & 1.000 & Bitung (pertumbuhan Ekonomi) \\
\hline 7 & 1.000 & Bolmong (kemiskinan) \\
\hline 8 & 1.000 & Bolmong (Pengangguran) \\
\hline 9 & 1.000 & Bolmong (pertumbuhan Ekonomi) \\
\hline 10 & 1.000 & Minahas (kemiskinan) \\
\hline 11 & 1.000 & Minahasa (Pengangguran) \\
\hline 12 & 1.000 & Minahasa (pertumbuhan Ekonomi) \\
\hline
\end{tabular}

Sumber : pengolahan data 2016

Dapat dilihat pada table di atas bahwa semua model dari model 1-12 menunjukan angka VIF $<10$ sehingga dapat diambil kesimpulan bahwa dari 12 model yang digunakan tidak terdapat gejala multikolinearitas

\section{Pengujian Statistik}

\section{Uji t-stat}

Dari hasil perhitungan yang telah diperoleh dilakukan pengujian t-hitung/statistik untuk mengetahui bagaimana pengaruh variabel bebas secara parsial terhadap Kemiskinan, pertumbuhan ekonomi dan pengangguran di Kota Bitung, Manado, Kabupaten Bolaang Mongondouw dan kabupaten Minahasa. Hipotesis dari uji ini adalah sebagai berikut,

Ho : $\beta_{1}=0$, variabel bebas tidak mempengaruhi variabel tak bebas

Hi : $\beta_{1} \neq 0$, variabel bebas mempengaruhi variabel tak bebas

Dengan menguji dua arah dalam tingkat signifikansi (Confidence Level atau $C L$ ) dan derajat kebebasan (degree of freedom $)=(\alpha, n-k)$, dimana $\alpha$ menunjukkan tingkat kepercayaan analisis, $\mathrm{n}$ menunjukkan jumlah observasi, dan $\mathrm{k}$ menunjukkan jumlah parameter termasuk konstanta, hasil pengujian akan menghasilkan dua kesimpulan menurut hipotesis di atas:

Bila $t_{\text {hitung }}<\mathrm{t}_{\text {tabel }}$ maka Ho tidak ditolak dan menolak Hi

Berarti variabel bebas secara individual tidak berpengaruh terhadap variabel tak bebas

Jika $t_{\text {hitung }}>\mathrm{t}_{\text {tabel }}$ dan $\mathrm{t}_{\text {hitung }}$ maka Ho ditolak dan Hi tidak ditolak

Berarti variabel bebas secara individual berpengaruh terhadap variabel dependen

\section{Variabel APBD Terhadap Kemiskinan}

Dari hasil estimasi model, maka diperoleh nilai t-statistik untuk variabel APBD terhadap Kemiskinan di tiap-tiap kabupaten/kota Sulut di dapatkan hasil sebagai berikut : 


\section{Tabel 6 hasil uji t-statistik terhadap kemiskinan di Kabupaten/Kota Sulawesi Utara}

\begin{tabular}{|c|c|c|c|}
\hline Kabupaten/kota & $\begin{array}{c}\text { Hasil ujit- } \\
\text { statistik }\end{array}$ & Sig & coefficient \\
\hline Kota Manado & -2.316 & .049 & -.633 \\
\hline Kota Bitung & 6.496 & .000 & -.917 \\
\hline $\begin{array}{c}\text { Kabupaten Bolaang } \\
\text { Mongondouw }\end{array}$ & -1.492 & .149 & -.493 \\
\hline Kabupaten Minahasa & -.997 & .348 & -.997 \\
\hline
\end{tabular}

Sumber : pengolahan data 2016

Untuk melihat apakah ada Pengaruh Linier Variabel Independen Exogenus Anggaran Pendapatan dan Belanja Daerah terhadap Variabel Dependen Endogenus Kemiskinan. Dapat dilihat pada tabel Coefficients(a) Menentukan besarnya taraf Signifikan sebesar 0,05 dan Degree of Freedom $\mathrm{DF}=\mathrm{n}-(\mathrm{K}+1)$ atau $\mathrm{DF}=10-(1+1)=8$. Dari ketentuan tersebut diperoleh $\mathrm{t}$ tabel sebesar 1.859 (untuk uji dua arah) Dalam perhitungan SPSS yang tertera pada tabel Coefficients di atas dimana tabel $t$ adalah untuk menunjukan bahwa adanya Pengaruh linier antara Variabel Independen APBD daerah terhadap Variabel Dependen Kemiskinan. Dimana dapat dilihat yang mempunyai pengaruh linear hanya di kota Bitung.

Berdasarkan hasil perhitungan di atas dapat dilihat bahwa pada tingkat signifikansi di bawah 5\% hanya ada Kota Bitung, sedangkan kabupaten/kota lainnya tidak memberi pengaruh yang signifikan terhadap penurunan angka kemiskinan di kabupaten kota masing-masing. Apabila dilihat pada coefficient di atas dapat diketahui bahwa meski semua nilai coefficient berada pada angka negative, dimana dapat dikatakan bahwa setiap kenaikan APBD sebesar $1 \%$ maka akan mereduksi tingkat kemiskinan sebesar nilai coefficient dari masing-masing kabupaten kota, namun yang berada pada tingkat kepercayaan di atas $95 \%$ hanya kota Bitung.

\section{Variabel APBD Terhadap Pertumbuhan Ekonomi}

Dari hasil estimasi model, maka diperoleh nilai t-statistik untuk variabel APBD terhadap pertumbuhan ekonomi di tiap-tiap kabupaten kota di dapatkan hasil sebagai berikut :

Tabel 7 hasil uji t-statistik terhadap Pertumbuhan Ekonomi di Kabupaten/Kota Sulawesi Utara

\begin{tabular}{|c|c|c|c|}
\hline Kabupaten/kota & $\begin{array}{c}\text { Hasil ujit- } \\
\text { statistik }\end{array}$ & Sig & coefficient \\
\hline Kota Manado & -.120 & .742 & -.120 \\
\hline Kota Bitung & 3.155 & 0.13 & .745 \\
\hline $\begin{array}{c}\text { Kabupaten Bolaang } \\
\text { Mongondouw }\end{array}$ & 7.857 & .000 & .941 \\
\hline Kabupaten Minahasa & 2.726 & .026 & .694 \\
\hline
\end{tabular}

Sumber : pengolahan data 2016 
Berdasarkan hasil perhitungan t-statistik dengan perbandingan t-tabel sebesar 1.859 dapat diketahui di Kota bitung, Kabupaten Bolaang Mongondouw dan Kabupaten Minahasa APBD mempunyai korelasi dengan pertumbuhan ekonomi yang terjadi, sedangkan di Kota Manado tidak ditemukan adanya korelasi antara APBD dan Pertumbuhan Ekonomi.

Dapat dilihat pula pada tingkat keyakinan di atas $95 \%$ hany ada Bolaang Mongondouw sedangkan sisanya berada pada tingkat keyakinan di bawah $95 \%$. Dan berdasarkan penghitungan coefficient di atas dapat dikalkulasikan bahwa setiap kenaikan sebesar $1 \%$ pada APBD masing-masing kota/kabupaten maka akan menaikan pertumbuhan ekonomi di Kota Bitung sebesar 0,74 \%, pada kabupaten Bolaang Mongondouw sebesar 0.94 \% dan Kabupaten Minahasa sebesar $0.69 \%$.

\section{Variabel APBD Terhadap Pengangguran}

Dari hasil estimasi model, maka diperoleh nilai t-statistik untuk variabel APBD terhadap pengangguran di tiap-tiap kabupaten kota di dapatkan hasil sebagai berikut :

Tabel 8 hasil uji t-statistik terhadap Penganggurandi Kabupaten/Kota Sulawesi Utara

\begin{tabular}{|c|c|c|c|}
\hline Kabupaten/kota & $\begin{array}{c}\text { Hasil ujit- } \\
\text { statistik }\end{array}$ & Sig & coefficient \\
\hline Kota Manado & -1.162 & .279 & -.380 \\
\hline Kota Bitung & -3.204 & .013 & -.750 \\
\hline $\begin{array}{c}\text { Kabupaten Bolaang } \\
\text { Mongondouw }\end{array}$ & -2.352 & .047 & -.639 \\
\hline Kabupaten Minahasa & -2.124 & .066 & -.601 \\
\hline
\end{tabular}

Sumber : pengolahan data 2016

Berdasarkan hasil perhitungan t-statistik di atas dan membandingkan dengan angka ttabel statistic sebesar 1.859 dapat diketahui bahwa dari 4 kabupaten/kota yang ada di Sulawesi utara didapatkan hasil bahwa tidak ada hubungan atau korelasi yang signifikan antara Anggaran Pendapatan Dan Belanja Daerah (APBD) dan tingkat pengangguran yang ada di masing-masing kabupaten/kota, baik di Kota Manado, Kota Bitung, Maupun, Kabupaten Minahasa dan kabupaten Bolaang Mongondou. Sehingga dapat disimpulkan bahwa APBD tidak memberi pengaruh pada angka pengangguran.

\section{Uji F-stat}

Uji $\mathrm{F}$ digunakan untuk mengetahui apakah variabel-variabel independen dalam persamaan regresi tersebut mempengaruhi variabel dependen secara bersamaan dengan tingkat signifikansi tertentu. Hipotesis dari uji ini adalah sebagai berikut, Ho : $\beta 1=\beta 2=\beta 3=0$

(tidak ada pengaruh yang berarti antara variabel independen terhadap variabel dependen)

$\mathrm{Ha}: \beta 1, \beta 2, \beta 3 \neq 0$ 
(ada pengaruh variabel independen terhadap variabel dependen)

Dengan tingkat signifikansi dan derajat kebebasan tertentu $\mathrm{F}_{(\alpha ; \mathrm{k}-1, \mathrm{n}-\mathrm{k}) \text {, dimana } \alpha}$ adalah tingkat kepercayaan, $\mathrm{n}$ menunjukkan jumlah observasi dan $\mathrm{k}$ menunjukkan jumlah parameter termasuk konstanta, hasil pengujian akan menghasilkan kesimpulan menurut hipotesa diatas yaitu:

Ho tidak ditolak jika $\mathrm{F}_{\text {hitung }}<\mathrm{F}$ tabel

Ho tidak ditolak berarti variabel yang diuji secara keseluruhan tidak mempunyai pengaruh yang berarti.

Ho ditolak apabila $\mathrm{F}_{\text {hitung }}>\mathrm{F}_{\text {tabel }}$

Ho ditolak berarti variabel yang diuji secara keseluruhan mempunyai pengaruh yang berarti.

Tabel 9 Perhitungan F Statistik

\begin{tabular}{|l|l|c|c|}
\hline N0 & Kabupaten/Kota (model) & F Tabel $\alpha=5 \%$ & F stat. \\
\hline 1 & Manado Kemiskinan & 5.362 & 5.12 \\
\hline 2 & Manado Pengangguran & 1.350 & 5.12 \\
\hline 3 & Manado Pertumbuhan Ekonomi & .116 & 5.12 \\
\hline 4 & Bitung Kemiskinan & 42.197 & 5.12 \\
\hline 5 & Bitung Pengangguran & 10.268 & 5.12 \\
\hline 6 & Bitung Pertumbuhan Ekonomi & 9.953 & 5.12 \\
\hline 7 & Minahasa Kemiskinan & .994 & 5.12 \\
\hline 8 & Minahasa Pengangguran & 4.513 & 5.12 \\
\hline 9 & MinahasaPertumbuhan Ekonomi & 7.431 & 5.12 \\
\hline 10 & Bolaang Mongondouw Kemiskinan & 2.554 & 5.12 \\
\hline 11 & Bolaang Mongondouw Pengangguran & 5.530 & 5.12 \\
\hline 12 & $\begin{array}{l}\text { Bolaang Mongondouw Pertumbuhan } \\
\text { Ekonomi }\end{array}$ & 61.729 & 5.12 \\
\hline
\end{tabular}

Sumber : Pengolahan data 2016

Berdasarkan hasil perhitungan yang telah dilakukan, diperoleh nilai $\mathrm{F}$ hitung/statistik dengan nilai $\mathrm{F}$ tabel $\mathrm{l}_{(0.05,2-1=1, \mathrm{n}-\mathrm{k}=9)}$ dengan hasil yang berbeda-beda untuk tiap model di setiap kabupaten/kota yang ada di sulwesi utara,

$>$ Dapat dilihat berdasarkan perbandingan di atas pada model pertama dapat dilihat bahwa secara keseluruhan pada model kemiskinan di Manado, ada pengaruh secara keseluruhan antara APBD terhadap kemiskinan

$>$ Pada model kedua dapat dilihat bahwa secara keseluruhan tidak ada pengaruh yang signifikan aantara APBD kota Manado dengan tingkat pengangguran

$>$ Pada model ketiga juga dapat diketahui bahwa tidak ada pengaruh secara keseluruhan antara APBD kota Manado dengan pertumbuhan ekonomi.

$>$ Dalam model ke empat dapat dilihat bahwa secara keseluruhan APBD kota Bitung mempunyai pengaruh yang berarti terhadap kemiskinan di kota Bitung

Pada model kelima juga dapat dilihat bahwa secara keseluruhan APBD kota Bitung mempunyai pengaruh yang berarti terhadap tingkat pengangguran di kota Bitung. 
> Pada model keenam dapat dilihat bahwa secara keseluruhan APBD kota Bitung mempunyai pengaruh yang berarti terhadap pertumbuhan ekonomi di kota Bitung

Pada model ketujuh dapat dilihat bahwa secara keseluruhan APBD kabupaten Minahasa tidak mempunyai pengaruh yang berarti terhadap kemiskinan di kabupaten Minahasa.

$>$ Pada model kedelapan juga dapat dilihat bahwa secara keseluruhan APBD kabupaten Minahasa tidak mempunyai pengaruh yang berarti pada angka kemiskinan di Kabupaten Minahasa.

$>$ Pada model kesembilan dapat dilihat bahwa secara keseluruhan APBD kabupaten Minahasa mempunyai pengaruh yang berarti pada pertumbuhan ekonomi Kabupaten Minahasa.

$>$ Dalam model sepuluh dapat dilihat bahwa secara keseluruhan APBD Kabupaten Bolaang Mongondouw ada pengaruh yang berarti terhadap kemiskinan di Bolaang Mongondouw

$>$ Dalam model sebelas dapat dilihat bahwa secara keseluruhan ada pengaruh yang berarti APBD kabupaten Bolaang Mongondouw terhadap tingkat kemiskinan di Bolaang Mongondouw

> Pada model terkahir dapat berdasarkan perbandingan antara $\mathrm{F}$ count dan $\mathrm{F}$ table ada pengaruh yang berarti APBD Bolaang Mongondouw terhadap pertumbuhan ekonomi.

\subsection{Koefisien Determinasi}

Dari hasil regresi terhadap masing-masing model ada maka didapatkan hasil RSquare sebagai berikut :

\section{Tabel 10 Perhitungan R-Square}

\begin{tabular}{|l|l|c|}
\hline N0 & Kabupaten/Kota (model) & Hasil R Square \\
\hline 1 & Manado Kemiskinan & .401 \\
\hline 2 & Manado Pengangguran & .144 \\
\hline 3 & Manado Pertumbuhan Ekonomi & .014 \\
\hline 4 & Bitung Kemiskinan & .841 \\
\hline 5 & Bitung Pengangguran & .562 \\
\hline 6 & Bitung Pertumbuhan Ekonomi & .554 \\
\hline 7 & Minahasa Kemiskinan & .111 \\
\hline 8 & Minahasa Pengangguran & .361 \\
\hline 9 & MinahasaPertumbuhan Ekonomi & .482 \\
\hline 10 & Bolaang Mongondouw Kemiskinan & .242 \\
\hline 11 & Bolaang Mongondouw Pengangguran & .409 \\
\hline 12 & Bolaang Mongondouw Pertumbuhan Ekonomi & .885 \\
\hline
\end{tabular}

Sumber : Pengolahan data 2016 
Dari hasil penghitungan didapatkan hasil sebagai berikut :

$>$ Pada model kemiskinan di Manado dapat diketahui bahwa variabel terikat mampu menjelaskan perubahan yang terjadi pada tingkat kemiskinan yang terjadi di kota Manado sebesar $40.1 \%$ sedangkan sisanya sebesar 59.9 dijelaskan oleh variabel lain yang tidak ada dalam penelitian

$>$ Pada model pengangguran di Manado berdasarkan hasil penghitungan diketahui bahwa variabel bebas hanya mampu menjelaskan sebesar $14.4 \%$ perubahan yang terjadi pada angka pengangguran yang ada di kota Manado

$>$ Pada model pertumbuhan ekonomi di Kota Manado berdasarkan hasil penghitungan didapatkan hasil bahwa variabel terikat hanya mampu menjelaskan perubahan yang terjadi pada pertumbuhan ekonomi kota Manado sebesar 1,4 \% sedangkan sisanya sebesar 98,6\% dijelaskan oleh variabel lain yang tidak ada dalam penelitian

$>$ Pada model kemiskinan Bitung dapat diketahui bahwa variabel terikat mampu menjelaskan perubahan yang terjadi pada tingkat kemiskinan di kota Bitung sebesar $84.1 \%$, sedangkan sisanya sebesar $15,9 \%$ dipengaruihi oleh variabel lain di luar penelitian.

> Pada model Pengangguran Bitung berdasarkan hasil penghitungan didapatkan hasil bahwa variabel terikat mampu menjelaskan perubahan yang terjadi pada tingkat pengangguran di Kota Bitung sebesar 56,2 \%, sedangkan sisanya sebesar 43,8\% dijaskan oleh variabel lain yang ada di luar penelitian.

> Pada model pertumbuhan ekonomi Bitung didapatkan hasil bahwa variabel terikat yang berada dalam model mampu menjelaskan perubahan yang terjadi pada pertumbuhan ekonomi kota Bitung sebesar 55,4 \% sedangkan

> Pada model Kemiskinan Minahasa berdasarkan hasil perhitungan didapatkan hasil bahwa variabel terikat mampu menjelaskan perubahan yang terjadi pada angka kemiskinan di Kabupaten Minahasa sebesar 11,1 \% sedangkan sisanya dijelaskan oleh variabel lain yang berada di luar penelitian.

> Pada model pengangguran Minahasa berdasarkan penghitungan didapatkan hasil bahwa variabel terikat yang berada dalam penelitian mampu menjelaskan perubahan yang terjadi pada pengangguran yang ada di kabupaten Minahasa sebesar $36.1 \%$ sedangkan sisanya sebesar 63,9\% dijelaskan oleh variabel lain yang tidak ada dalam penelitian.

> Pada model pertumbuhan ekonomi Minahasa berdasarkan penghitungan didapatkan hasil bahwa variabel terikat yang berada dalma penelitian mampu menjelaskna perubahan yang terjadi pada pertumbuhan ekonomi sebesar 48,5 $\%$ sedangkan sisanya sebesar 51,5\% dijelaskan oleh variabel lain yang berada di luar penelitian.

> Pada model Kemiskinan Kabupaten Bolaang Mongondouw berdasarkan penghitungan yang dilakukan didapatkan hasil bahwa variabel terikat yang berada di dalam model mampu menjelaskan perubahan yang terjadi di Kabupaten Bolaang Mongondouw sebesar $24.2 \%$ sedangkan sisanya dipengaruhi oleh variabel lain yang berada di laur penelitian.

Pada model pengangguran Bolaang Mongodouw berdasarkan hasil perhitungan didapatkan hasil bahwa variabel terikat yang berada dalam model 
mampu menjelaskan perubahan yang terjadi pada angka pengangguran sebesar $40.9 \%$ sedangkan sisanya sebesar 59,1\% dijelaskan oleh variabel lain yang berada di luar penelitian.

Pada model Pertumbuhan Ekonomi Bolaang Mongondouw berdasarkan hasil perhitungan didapatkan hasil bahwa variabel terikat yang berada di dalam model mampu menjelaskan perubahan yang terjadi pada pertumbuhan ekonomi Kabupaten Bolaang Mongondouw sebesar 88.5 \% sedangkan sisanya sebesar $11,5 \%$ dijelaskan oleh variabel lain yang berada di luar penelitian

\section{Pembahasan}

Berdasarkan hasil pengujian yang dilakukan terhadap model 1-12 di kabupaten/kota Sulawesi Utara mendapatkan beberapa hasil yang cukup berbeda satu sama lain. Apalagi mengenai dampak dari pengelolaan Anggaran Pendapatan dan Belanja Daerah (APBD) di kabupaten/kota masing-masing untuk mempengaruhi perekonomian yang dimiliki, kesejahteraan masyarakat yang ada di daerah masingmasing dilihat dari angka kemiskinan serta tingkat pengangguran.

Seperti dapat dilihat bagaimana pemerintah di tiap Kabupaten/Kota melalui pengelolaan APBD di masing-masing daerah mempengaruhi tingkat kemiskinan, dari hasil penghitungan didapatkan hasil bahwa dari 4 sampel kabupaten/kota yang ada di Sulawesi Utara hanya Kota Bitung melalui APBDnya mampu mereduksi tingkat kemiskinan di daerahnya secara signifikan. Sedangkan untuk Manado, Minahasa dan Bolaang Mongondouw berdasarkan penghitungan yang dilakukan belum mampu mempengaruhi secara signifikan tingkat kemiskinan yang dimiliki di daerah masingmasing.

Selanjutnya untuk model pengangguran di kabupaten/kota penelitian, mendapatkan hasil bahwa hanya di Kota Bitung yang mampu mereduksi pengangguran yang terjadi melalui alokasi anggaran yang dimiliki, sedangkan untuk daerah lainnya, memiliki pengaruh namun tidak secara signifikan perubahan yang terjadi pada alokasi anggaran mempengaruhi tingkat pengangguran yang dimiliki di daerah masing-masing.

Sedangkan untuk model pertumbuhan ekonomi kembali kota Bitung mampu mempengaruhi tingkat pertumbuhan ekonominya secara signifikan melalui alokasi APBD yang dimiliki, namun untuk model ini ada juga Bolaang Mongondouw yang mampu mempengaruhi pertumbuhan ekonomi yang dimiliki bahkan berada pada tingkat pengaruh yang jauh lebih besar dari kota Bitung. Sedangkan untuk Manado dan Minahasa belum mampu untuk mempengaruhi pertumbuhan ekonomi yang dimiliki melalui alokasi anggaran APBD.

Dari hasil perhitungan diatas dapat dilihat bahwa perekonomian yang dimiliki oleh tiap daerah dengan berbagai sektor unggulan masing-masing tentunya mendapat outcome yang berbeda pula. Seperti di Kota Bitung dimana baik angka kemiskinan, pengangguran serta pertumbuhan ekonomi mendapatkan pengaruh yang cukup besar dari pengalokasian APBD yang dimiliki pemerintah, hal ini berarti kota Bitung sendiri apalagi melihat alokasi anggaran yang dimiliki memang masih banyak 
berharap sokongan dana dari pemerintah pusat namun dengan pengalokasian anggaran yang tepat sasaran mampu mencapai tingkat kesejahteraan masyarakat yang semakin baik sejalan dengan waktu, serta dengan tingkat pertumbuhan ekonomi yang juga terus konsisten maka akan berdampak pada pembangunan sumber daya manusia yang semakin baik di kota Bitung.

Kota Manado sebagai satu-satunya daerah di Sulawesi Utara yang mempunyai tingkat kemandirian di atas $20 \%$, berdasarkan hasil uji yang dilakukan, pemerintah kota Manado melalui APBDnya tidak mempunyai pengaruh yang signifikan baik untuk mereduksi tingkat kemiskinan, pengangguran ataupun pertumbuhan ekonomi yang dimiliki. Hal ini mengindikasikan bahwa selain kemampuan pemerintah dalam mendapatkan pendapatan asli daerah yang semakin baik tiap tahunnya, perekonomian di Manado semakin berkembang untuk itu mengapa meskipun dengan alokasi anggaran yang semakin baik tiap tahunnya Manado tidak meberikan pengaruh yang signifikan terhadap pertumbuhan ekonomi, ataupun mereduksi tingkat pengangguran serta kemiskinan yang ada di Kota Manado, hal ini bisa saja terjadi apabila programprogram yang dimiliki pemerintah kota Manado berorientasi pada pembangunan jangka menengah atau panjang sehingga hasil dari upaya-upaya pembangunan ini belum langsung terlihat.

Di Minahasa juga terjadi hal yang hamper sama dengan yang terjadi di Kota Manado, namun apabila dilihat dari perkembangan anggaran yang dimiliki serta tingkat kemandirian keuangan Kabupaten Minahasa maka bisa dikatakan APBD yang dimiliki Kabupaten Minahasa juga tidak memberikan pengaruh yang signifikan terhadap penurunan kemiskinan, pengangguran serta pertumbuhan ekonomi, hal yang serupa dengan kota Manado namun tidak persis sama. Karena apabila melihat data yang ada maka dapat diketahui bahwa perekonomian serta kemandirian di kota Manado berjalan amat cepat sedangkan Kabupaten Minahasa tidak. Hal ini bisa saja outcome dari program-program pembangunan yang dimiliki oleh masing-masing daerah berbeda karena program yang dimiliki serta cara menjalankan yang berbedabeda antara pemerintahan Kota Manado dan Kabupaten Minahasa.

Untuk Bolaang Mongondouw hanya pertumbuhan ekonomi yang mampu dipengaruhi secara signifikan alokasi anggaran yang dimiliki oleh pemerintah melalui APBD, hal ini mengindikasikan bahwa APBD yang dimiliki oleh Kabupaten Bolaang Mongondouw dalam 10 tahum terakhir belum mampu memberi kontribusi maksimal dalam rangka mereduksi tingkat kemiskinan dan angka pengangguran yang dimiliki.

Melihat hasil ini dengan mengesampingkan program yang dimiliki maka kota Bitung melalui APBDnya mampu mempengaruhi pertumbuhan ekonomi, menurunkan tingkat kemiskinan dan angka pengangguran yang dimiliki secara signifikan, sedangkan untuk tiga kabupaten lainnya terhadap pertumbuhan ekonomi, tingkat kemiskinan dan angka pengguran belum mampu memberi pengaruh yang maksimal.

\section{KESIMPULAN DAN SARAN}

Berdasarkan pada teori-teori dan pembuktian baik secara empiris maupun ekonomi mengenai pengaruh APBD terhadap pertumbuhan ekonomi di daerah-daerah yang 
diteliti, maupun penurunan tingkat kemiskinan serta angka pengangguran di kabupaten/kota Sulawesi Utara dari tahun 2006 hingga tahun 2015 dapat ditarik kesimpulan dan saran sebagai berikut.

\section{Kesimpulan}

1. Di kota Manado alokasi Anggaran Pendapatan dan Belanja Daerah (APBD) tidak memberi pengaruh yang signifikan terhadap pertumbuhan ekonomi, penurunan angka kemiskinan serta penurunan tingkat pengangguran. Meskipun alokasi anggaran terus bertambah tiap tahunnya namun ternyata dengan jumlah anggaran yang terus meningkat ini belum memberi pengaruh yang signifikan, dikarenakan perekonomian di Manado yang kian berkembang dan kian tingginya peranan sektor swasta di dalam perekonomian.

2. Di kota Bitung pengaruh APBD terhadap perekonomian masih amat besar bahkan berdasarkan hasil penelitian didapatkan hasil bahwa baik pertumbuhan ekonomi, pengangguran maupun tingkat kemiskinan. Hal ini dikarenakan pengalokasian anggaran dari pemerintah berhubungan dan berpengaruh langsung pada perekonomian.

3. Di Minahasa APBD tidak memberi pengaruh pada perekonomian, baik dalam pertumbuhan ekonomi, penurunan angka kemiskinan dan penurunan angka pengangguran, hal ini disebabkan oleh derajat desentralisasi kabupaten Minahasa masih amat kecil sehingga program-program pembangunan di daerah masih mengikuti arahan dari pusat. Hal ini bisa menyebabkan kurang fokusnya pembangunan di daerah dan kurang mengena pada prioritas daerah.

4. Di Kabupaten Bolaang Mongondouw alokasi anggaran APBD memberi kontribusi positif pada perekonomian terutama dalam menaikan angka pertumbuhan ekonomi, namun kurang memberi pengaruh yang positif dan signifikan terhadap penurunan angka kemiskinan, serta angka pengangguran yang ada di Bolaang Mongondouw.

\section{Saran}

1. Mengingat peranan Anggaran Pendapatan dan Belanja Daerah masih menjadi salah satu factor penentu dalam menumbuhkan perekonomian dan memacu efek domino dalam upaya memerangi kemiskinan, serta pengangguran di daerah, maka perlu ditinjau kembali bagaimana tata cara perencanaan dan pengalokasian serta pelaksanaan kegiatan anggaran agar dapat memberi kontribusi maksimal bagi perekonomian terutama dalam upaya memerangi kemiskinan dan pengangguran.

2. Daerah-daerah di Sulawesi Utara perlu untuk menaikan derajat kemandirian yang dimiliki agar mampu membangun daerah sesuai dengan prioritas daerah masing-masing, karena peranan pemerintah daerah yang dianggap lebih mampu untuk menjalankan kegiatan dan mengetahui kebutuhan daerah. Dengan adanya kemampuan daerah yang lebih baik maka baik secara langsung maupun tidak langsung akan memberi efek pada perekonomian dan berdampak pada kesejahteraan masyarakat. 


\section{Pustaka}

Aisyah, Nyayu, 2004. Keterkaitan antara indicator pembangunan ekonomi dan ikdeks pembangunan manusia dalam perekonomian Indonesia analisis antar wilayah. Skripsi fakultas ekonomi dan manajemen, institute pertanian Bogor.

Ala, Andre Bayo, 1988. Kemiskinan dan strategi memerangi kemiskinan, Yogyakarta, Penerbit Liberty.

Kaho, Josef Riwu. 1988. Prospek Otonomi di Negara Indonesia Jakarta. PT. Raja Grafindo Persada.

Kuncoro Mudrajad. 2000, Ekonomi Pembangunan, Teory Masalah dan Kebijakan, Penerbit UPP AMP YKPN, Yogyakarta.

Nugroho dan Rochmin Danuari , 2004. Pembangunan Wilayah, perspektif Ekonomi social dan lingkungan, pustaka LP3ES, Jakarta.

Tarigan, R,2006, perencanaan pembangunan wilayah, edisi revisi, Bumi Aksara, Jakarta panduan.

Todaro, Michael, P dan Stephen C Smith, 2006, Pembangunan Ekonomi, Edisi Kesembilan, Jakarta : Erlangga.

Sadono Sukirno, 2006, mikro ekonomi, teory pengantar, edisi ketiga, Jakarta : raja grafindo persada.

Undang-undang nomor 17 tahun 2003 tentang pengelolaan Keuangan Negara.

Undang-undang No 33 tahun 2004 tentang keuangan daerah. 